\title{
Pre-treatment of cheese milk: principles and developments
}

\author{
Alan L. KeLLY ${ }^{1 *}$, Thom HUPPERTZ ${ }^{2}$, Jeremiah J. SHEEHAN ${ }^{3}$ \\ ${ }^{1}$ Department of Food and Nutritional Sciences, University College Cork, Ireland \\ ${ }^{2}$ NIZO Food Research, Ede, The Netherlands \\ ${ }^{3}$ Moorepark Food Research Centre, Fermoy, Co. Cork, Ireland
}

\begin{abstract}
Classically, very few pre-treatments are applied to milk for cheese-making, with some cheese varieties simply made from raw whole milk, but most made from pasteurised milk of which the composition (e.g., fat:protein ratio) may have been standardized. However, there has been consistent interest in more novel and sophisticated strategies for pre-treatment of cheese-milk. Approaches explored include the use of alternative processing technologies (e.g., membrane filtration, high-pressure treatment, homogenisation, heat treatments more severe than pasteurisation) or addition of sources of protein or milk solids (e.g., milk powders, whey protein products) or enzymes. The principal reasons for such pre-treatments of cheese-milk are: (1) to control the microbiology of the raw milk and the resulting cheese better than is possible by pasteurisation (e.g., inactivation or removal of spores, control of non-starter lactic acid bacteria); (2) increasing the yield of cheese, e.g., through heat- or pressure-induced incorporation of whey proteins, or enhancing sensory properties of reduced fat cheese by direct addition of microparticulated whey proteins; (3) manipulation of cheese ripening, e.g., reducing the likelihood of off-flavour development by inactivation of enzymes or accelerating ripening through increasing enzyme-substrate interactions; or (4) improving the texture and other functional properties, e.g., melting. Finally, the considerations for manufacture and ripening of different cheese varieties, or sub-classes of specific varieties (e.g., low-fat cheese) will clearly differ and add to the complexity of the technological options available. This article will review the key principles for pre-treatment of cheese-milk, as summarised briefly above.
\end{abstract}

milk / cheese / heat treatment / membrane separation / high pressure / homogenisation / standardisation

摘要 - 干酪原料奶预处理的原理及其进展。本文综述了干酪生产原来奶预处理的原理及其 进展。传统干酪生产很少使用原料乳预处理技术, 许多品种的干酪直接用生鲜乳加工, 即使 大多数以巴氏杀菌乳生产的干酪也只是对其组成 (脂肪和蛋白质的比率) 进行标准化。但是, 干酪用原料乳预处理作为一种新兴的技术已经引起广泛关注, 人们不断开发出来新的方法, 如加工技术 (膜过滤、高压处理、均质、比巴氏杀菌有效的热处理) ; 添加蛋白质、乳固形 物 (如乳粉、乳清蛋白), 或外源酶。对干酪用原料乳进行预处理的主要原因有: (1) 控制原 料乳中的微生物, 使干酪质量优于巴氏杀菌干酪 (如去除芽狍或使其失活、控制非发酵剂乳 酸菌): (2) 增加干酪的产量, 如通过热处理或加压促进乳清蛋白与酪蛋白的融合, 或者通过直 接添加微粒化的乳清蛋白来改善低脂干酪的感官性质; (3) 控制干酪成熟, 如减少由于酶失 活而引起干酪产生异味的可能性, 或者通过提高酶与底物相互作用程度来加速干酪的成熟; (4) 改进质构及功能性, 如融化性。由于不同种类干酪或某一种类干酪的亚类 (如低脂干酪) 生产和成熟过程所要考虑的因素完全不同,也增加了所选技术的复杂性。

\section{奶 / 干酪 / 热处理 / 膜分离 / 高压 / 均质 / 标准化}

* Corresponding author (通讯作者): a.kelly@ucc.ie 
Résumé - Pré-traitement du lait de fabrication de fromage : principes et avancées. Classiquement, très peu de pré-traitements sont appliqués au lait de fabrication de fromage : quelques variétés de fromage sont faites simplement à partir de lait entier cru, mais la plupart d'entre elles sont fabriquées à partir de lait pasteurisé dont la composition (par exemple rapport matière grasse/protéine) a pu être standardisée. Cependant, un intérêt constant s'est manifesté pour des stratégies nouvelles et plus sophistiquées pour le pré-traitement du lait de fromagerie. Les approches explorées incluent l'utilisation de technologies de traitement alternatives (par exemple filtration membranaire, haute pression, homogénéisation, traitements thermiques plus sévères que la pasteurisation) ou addition de sources de protéines ou de matière sèche de lait (par exemple poudres de lait, protéines de lactosérum) ou d'enzymes. Les principales raisons de tels pré-traitements du lait de fabrication fromagère sont : (1) de contrôler la microbiologie du lait cru et du fromage résultant, mieux que ce qui est possible par pasteurisation (par exemple inactivation ou retrait des spores, contrôle des bactéries lactiques non levain); (2) d'accroître le rendement en fromage, par exemple en induisant l'incorporation de protéines de lactosérum par traitement thermique ou haute pression, ou d'améliorer les propriétés sensorielles du fromage allégé en matière grasse par l'addition directe de protéines de lactosérum microparticulées; (3) d'orienter l'affinage du fromage, par exemple en réduisant la probabilité de développement de défauts de flaveur par inactivation d'enzymes ou en accélérant l'affinage en accroissant les interactions enzyme-substrat ; ou (4) d'améliorer la texture et les autres propriétés fonctionnelles, par exemple la fonte. Finallement, les facteurs à considérer pour la fabrication et l'affinage des différentes variétés de fromage, ou classes de variétés spécifiques (par exemple fromages allégés) vont différer clairement et augmenter la complexité des options technologiques disponibles. Cet article passe en revue les principes clés pour le pré-traitement du lait de fabrication de fromage tels que résumés brièvement précédemment.

lait / fromage / traitement thermique / séparation par membrane / haute pression / homogénéisation / standardisation

\section{INTRODUCTION}

For centuries, milk for cheese-making was subjected to no pre-treatment before curdling, and many cheese varieties worldwide are still made from raw milk, particularly, but not exclusively, artisanal cheeses. However, predominantly for reasons of safety, but also consistency of quality, and manipulation of product characteristics, most cheese-making today involves the treatment of milk by one or more processing steps prior to addition of coagulant and starter culture.

Perhaps the simplest and earliest technological intervention, driven by safety concerns, was the pasteurisation of milk, first carried out in vats or kettles at temperatures around $63-65{ }^{\circ} \mathrm{C}$ (low-temperature, long-time, LTLT, pasteurisation) and more recently in continuous-flow plate heat exchangers at $72-74{ }^{\circ} \mathrm{C}$ for $15-30 \mathrm{~s}$ (hightemperature, short-time, HTST, pasteurisation). For a high proportion of cheese varieties, pasteurisation is the sole treatment applied to the cheese-milk. Pasteuri- sation also inactivates some enzymes, reverses shifts in the mineral balance of milk induced by cold storage, and influences the microflora of non-starter lactic acid bacteria (NSLAB) in the final cheese. It is primarily for the latter reason that many cheese-makers prefer to continue to use raw milk, as the contribution of NSLAB bacteria to cheese flavour is felt to be unacceptably impaired by pasteurisation. There has also been interest for some time in the application of heat treatments more severe than pasteurisation, which will result in significant denaturation of whey proteins and their resulting incorporation into cheese curd, with significant effects on cheese yield and composition.

In several varieties, or industrial production settings, the consistency of composition of cheese may also be controlled by standardisation of the incoming milk, generally in terms of manipulation of the ratio of fat to total protein or casein, by centrifugal separation and proportional mixing of cream whole milk and/or skim 
milk, by membrane filtration, or by addition of sources of milk protein.

In addition, in recent years, there have been studies of application of a number of new approaches to processing of cheesemilk, including the application of technologies new either to cheese production or to food processing in general, to achieve certain product or process benefits; these include use of homogenisation, treatment at high pressures, and addition of exogenous enzymes other than those required strictly for coagulation of the milk.

This review will provide an overview of the broad approaches to pre-treatment of cheese-milk mentioned briefly above (see summary in Tab. I). A particular focus will be given to recent studies of the applications of novel and innovative processing strategies.

\section{PRINCIPLES OF CHEESE- MAKING}

The fundamental physico-chemical principle under-pinning the conversion of milk to a cheese curd is the destabilisation of the casein micelles to such an extent that a gel is formed which, when cut, synereses in a manner which can be accelerated by mechanical stirring and/or mild heating (for general reviews on cheese manufacture and ripening, see [38-41]). This yields curd particles which can readily be recovered from the bulk aqueous serum phase of the milk, i.e., whey. In parallel, cultures of lactic acid bacteria added almost concurrently with the coagulant begin to grow and metabolise lactose to lactic acid, lowering the $\mathrm{pH}$ of the curd and ultimately playing a key role in the development of cheese flavour, through the release upon death and lysis of a range of catabolic enzymes which hydrolyse or otherwise convert milk constituents entrapped in the curd to a range of flavour and aroma compounds. Within a short time of the addition of coagulant and culture, the curd and whey are separated and the curd is pressed to enable fusion into a solid visco-elastic mass; this is then stored under conditions which allow the requisite biochemical reactions to be catalysed by the cheese micro-flora, which principally consists of the starter bacteria mentioned, but may also include other (non-starter) lactic acid bacteria and, in some varieties, yeasts and moulds deliberately added. During the storage, or ripening, period, enzymes within the coagulant and also arising from the milk itself break down the coagulated casein matrix, resulting in changes in cheese texture.

The broad principles outlined summarise the principle of manufacture of what are called rennet-coagulated cheeses, which represent the vast majority of both cheese varieties and actual tonnage of cheese produced globally and are the only cheese varieties dealt with in this review. The huge diversity of cheese varieties, from Pamesan (dry, crumbly and pungent) to Camembert (soft and mould-encrusted) results from surprisingly minor alterations in these core principles, such as the start of culture (bacterial and mould, if used), the extent to which whey is removed by stirring, cooking or pressing (greater whey removal leads to lower-moisture, harder, cheese) and the conditions during ripening (particularly temperature and relative humidity).

To consider the impact of milk processing technologies on cheese, it is important to consider what the milk contributes to cheese, as it is clear that much of cheesemaking relies on external agents added to the milk (coagulant and cultures) and operations applied to the resulting curd. The key constituents, properties and populations of milk which are of interest to the cheese-maker are summarised in Table I.

Clearly, there are numerous potential advantages to applying more ambitious technological strategies for processing 
Table I. Milk constituents, properties and populations of interest for cheese-making.

\begin{tabular}{|c|c|c|}
\hline Parameter & Significance for cheese-making & Reasons and strategies for manipulation \\
\hline Casein & $\begin{array}{l}\text { Forms rennet gel, synereses to yield } \\
\text { cheese curd }\end{array}$ & $\begin{array}{l}\text { Increase level (addition of milk protein } \\
\text { source) either of total protein, or relative } \\
\text { to fat content (standardisation), or change } \\
\text { properties (enzyme addition) }\end{array}$ \\
\hline Fat & Contributes to cheese texture and yield & $\begin{array}{l}\text { Increase or decrease fat content relative to } \\
\text { total composition or protein level (stan- } \\
\text { dardisation); incorporate more directly into } \\
\text { cheese curd through interactions with pro- } \\
\text { tein (homogenisation); accelerate release of } \\
\text { volatile flavour compounds (enzyme addi- } \\
\text { tion) }\end{array}$ \\
\hline $\begin{array}{l}\text { Whey } \\
\text { protein }\end{array}$ & Normally largely lost in whey & $\begin{array}{l}\text { Incorporate into curd to increase yield (heat } \\
\text { treatment, high-pressure treatment) }\end{array}$ \\
\hline Water & $\begin{array}{l}\text { Major constituent of cheese; level may be } \\
\text { characteristic of particular varieties }\end{array}$ & $\begin{array}{l}\text { Increase level to increase yield (heat treat- } \\
\text { ment, high-pressure treatment) but may } \\
\text { impair quality }\end{array}$ \\
\hline Bacteria & $\begin{array}{l}\text { Raw milk microflora either intact (raw milk) } \\
\text { or pathogens and many spoilage and non- } \\
\text { starter bacteria eliminated, but not spore- } \\
\text { forming species (pasteurised milk) }\end{array}$ & $\begin{array}{l}\text { Increase efficiency of removal of spore- } \\
\text { forming bacteria for some species (mem- } \\
\text { brane filtration) }\end{array}$ \\
\hline
\end{tabular}

cheese-milk, in terms of manipulating yield, composition, microbiological quality, and even biochemistry of ripening. However, in many cases actual implementation of new strategies has met with significant hurdles or barriers to implementation, and this review will consider these challenges alongside the possible advantages of each approach discussed.

\section{HEAT TREATMENTS OTHER THAN PASTEURISATION}

As outlined above, milk for cheese manufacture is heated to eliminate pathogenic bacteria, to minimise damage to caseins by proteolytic bacteria on storage or to incorporate heat-denatured whey proteins in curd, thereby improving cheese yield [7]. Furthermore, more severe heat treatment of milk may be applied to inactivate spores from Clostridium tyrobutyricum by $4 \mathrm{log}$ cycles and thus minimise the late blowing gas defect during cheese ripening [124].

Heat treatment of milk at conditions more severe than those used for conventional pasteurisation results in denaturation of whey proteins, interactions between whey proteins and casein micelles, and transfer of soluble calcium, magnesium and phosphate to the insoluble colloidal state. Casein micelles are very stable at high temperatures, although changes in zeta potential, size, hydration of micelles and some association-dissociation reactions do occur under severe heat treatments [37,126-129]. Denaturation of whey proteins exposes side chain groups originally buried in the native structure, particularly reactive thiol groups, and the unfolded proteins may self-aggregate or interact with casein micelles, through interactions with $\kappa$-casein. Ionic strength, $\mathrm{pH}$ and the concentrations of calcium and 
protein influence the extent of denaturation of the whey proteins $[24,100,129]$. The extent of association of denatured whey protein with casein micelles is dependent on the $\mathrm{pH}$ of the milk prior to heating, levels of soluble calcium and phosphate, milk solids concentration and mode of heating (direct or indirect).

For cheese-makers, the principal interest has been in increasing yield by exploiting this heat-induced association of caseins with whey proteins, while attempting to minimise undesirable changes in cheese quality. The effects of heat treatment at temperatures between 72 and $140{ }^{\circ} \mathrm{C}$ for holding times between $15 \mathrm{~s}$ and $5 \mathrm{~min}$ on whey protein denaturation prior to incorporation into cheese were reported by Law et al. [80]. Heat treatment of milk at $\sim 110^{\circ} \mathrm{C}$ for $60 \mathrm{~s}$ increased protein recovery in curd by $10 \%$ [6]. Where facilities to heat to temperatures $>100{ }^{\circ} \mathrm{C}$ are not available, increasing milk $\mathrm{pH}$ prior to heating increases levels of whey protein denaturation [9].

In the cheese vat, high heat treatment of milk prolongs rennet coagulation times and reduces the strength of rennet gels [5, $26]$, leading to impaired syneresis [10,92, 115]. The adverse effects on coagulation are attributed to the inhibition of hydrol$y$ sis of $\kappa$-casein by chymosin due to the $\beta$-lactoglobulin/ $\kappa$-casein complex at the micelle surface impairing the accessibility of $\kappa$-casein to the coagulant $[55,59,139]$, to reduced reactivity of renneted micelles with attached denatured whey proteins to aggregation, or to a reduction in the concentration of micellar calcium $[139,142]$. Reduced shrinkage of the para-caseinwhey protein network promotes increased water-binding [145], leading to poor coagulation and syneresis properties, increased set-to-cut times, soggy curds with poor matting ability, ragged curd chips and poor curd fusion during cheese manufacture [48, 92]. Gel-forming properties of high-heat-treated milks may be partly restored by ultrafiltration of milk to higher protein levels prior to cheese manufacture, reducing $\mathrm{pH}$ and increasing milk temperature during coagulation, increasing the level of added rennet and/or by the addition of $\mathrm{CaCl}_{2}$ to the cheese-milk [54, 55] or by $\mathrm{pH}$ cycling [129]. Acidification of heated milks reduces charge repulsion and increases solubilisation of colloidal calcium [22]. Acidification to $\mathrm{pH} 5.8$ or pH 6.2 prior to renneting of strongly heated milks increases cheese yield $[5,8,10]$ and $\mathrm{pH}$ cycling (acidification to $\mathrm{pH} 5.5$, overnight storage at $4{ }^{\circ} \mathrm{C}$ and adjustment to $\mathrm{pH}$ 6.2) prior to renneting has been shown to increase moisture and protein contents in Cheddar cheese [70] although that study did not report on cheese texture and sensory properties.

High heat treatment increases cheese yield and retention of whey protein and moisture in cheese and reduces the level of calcium and phosphorus due to reduced dry matter and increased whey protein content $[7-9,129]$. Flavour intensity is reduced in cheeses made from strongly heated milk [5, 8, 48] but bitterness was largely eliminated by a reduction in rennet quantities used [6].

Guinee et al. [48] attributed decreased cheese firmness with increased heating severity of milk to increased cheese moisture and decreased protein content. Adjustment of $\mathrm{pH}$ to 6.2 prior to renneting resulted in Cheddar cheese with a texture comparable to control cheese $[5,8]$ and Banks et al. [9] reported that manipulation of $\mathrm{pH}$ prior to heating had a significant effect on melt characteristics of a Cheddartype cheese.

Calvo et al. [23] reported greater breakdown of $\beta$-casein during ripening of Cheddar-type cheese manufactured from milk heated to $110{ }^{\circ} \mathrm{C}$ for $30 \mathrm{~s}$ than in cheese made from pasteurised milk, but Benfeldt et al. [12] attributed reduced hydrolysis of $\beta$ - and $\alpha_{\mathrm{s} 2}$-caseins in Danbo cheese made from milks heated 
to $90{ }^{\circ} \mathrm{C}$ for $60 \mathrm{~s}$ to thermal inactivation of the plasminogen activation system and heat-induced interactions between the plasminogen activation system and $\beta$-lactoglobulin. Guinee et al. [55] reported higher levels of primary proteolysis and reduced levels of smaller peptides and amino acids in cases of increased levels of whey protein denaturation in cheeses manufactured from UF retentate produced from strongly heated milk.

From studies of other varieties, severe heat treatment of milk resulted in a more open microstructure in Quarg [76], while Camembert-type cheese produced from severely heated milk had a higher yield and flavour, body and texture attributes similar to that of control cheeses made from pasteurised milk [43].

\section{CARBON DIOXIDE TREATMENT OF CHEESE-MILK}

There has been interest for some time in the use of carbon dioxide $\left(\mathrm{CO}_{2}\right)$ as a treatment for milk for preservation and technological reasons, due to its solubility in milk and inhibitory effect against a broad spectrum of micro-organisms [61]. It has been shown that addition of $\mathrm{CO}_{2}$ to raw milk decreased proteolysis, due to effects on both microbial growth and concomitant protease production and inhibited plasmin activity due to $\mathrm{pH}$ reduction; lipolysis was also retarded, probably due to reduced microbial growth [90].

A small number of studies have considered the possible use of such treatment prior to cheese-making. Nelson et al. [103] injected $\mathrm{CO}_{2}$ into milk to a level of $1600 \mathrm{ppm}$ after pasteurisation, which reduced $\mathrm{pH}$ to around 5.9, and made Cheddar cheese using normal levels of coagulant and starter addition. Milk treated with $\mathrm{CO}_{2}$ had lower whey $\mathrm{pH}$ at drainage, shorter total make time, and altered yield due to increased losses of calcium and fat, and increased salt retention. When cheese made using $\mathrm{CO}_{2}$ addition was ripened, cheese retained $\mathrm{CO}_{2}$ and treated cheese showed accelerated proteolysis, perhaps due to changes in substrate availability of increased retention or activity of chy$\operatorname{mosin}[104]$.

\section{HIGH-PRESSURE TREATMENT OF CHEESE-MILK}

High-pressure (HP) treatment of food has progressed in a relatively short space of time from a research subject of academic curiosity limited by perceived huge expense of use at industrial scale to a commercially realistic processing option, albeit for specific niche applications such as oysters, meat, guacamole and fruit products, including juices and smoothies. While these applications have grown rapidly within the last ten years, applications for dairy products have been notably absent; however, within the last year applications for treatment of processed cheese spreads (Spain) and functional and fermented dairy products (New Zealand) have been launched. The relative slowness of transfer of research in dairy products to market applications does not reflect a lack of potential interest; in contrast, whereas, for many of the products listed above, HP treatment results in microbial or enzymatic inactivation without loss of nutrients or flavour attributes (the principal advantage of using HP for these products), the effects of pressure on milk are far more complex, and often unique.

HP treatment principally exerts effects on macromolecules with complex structures, changing their structure and properties; as milk proteins are an enormously complex protein system, it is perhaps not surprising that dramatic changes occur under pressure, with repercussions 
for a whole range of milk and dairy product properties. The principal heatinduced change in milk proteins, denaturation of whey proteins, as discussed earlier, also occurs under pressure, with $\beta$-lactoglobulin being more susceptible to denaturation, at pressures above $100 \mathrm{MPa}$ (the typical units of pressure, where $1 \mathrm{MPa}$ is 10 times atmospheric pressure), than $\alpha$-lactalbumin, which is significantly denatured only at or above $400 \mathrm{MPa}$ [65].

However, arguably the most interesting effects of pressure concern the casein micelles, which change little at normal milk processing temperatures, except for the interactions with whey proteins mentioned. Depending on the pressure applied, duration and temperature of treatment and $\mathrm{pH}$ of milk, HP treatment of milk can result in aggregation of casein micelles (around $250 \mathrm{MPa}$ ) or significant dissociation (at pressures above $400 \mathrm{MPa}$ ). These phenomena have been shown to be due to the extent to which reassociation occurs after varying extents of pressure-induced disruption of the cohesive forces maintaining the structural integrity of casein micelles, e.g., the extent of solubilisation of colloidal calcium phosphate (CCP) [65].

Such fundamental changes in the characteristics of the basic building blocks of milk gels have predictably profound effects on the cheese-making properties of milk. Rennet coagulation time, for example, may be reduced by treatment at 100-300 MPa, but increased following more severe treatments [113, 150]. Huppertz et al. [67] showed that HP treatment increased wet curd yield, by up to $25 \%$ after treatment at $600-800 \mathrm{MPa}$, due to both incorporation of denatured whey protein and increased moisture retention. The combined effects of heat and pressure on rennet coagulation have also been reported [87], and it has been shown that HP treatment can modulate the negative effects of excessive heat treatment on cheese-making properties of milk [68].
There have been contradictory reports on the effect of HP treatment on acidification of milk by lactic acid bacteria, with Pandey et al. [113] reporting a reduced rate of $\mathrm{pH}$ change in HP-treated milk relative to raw or pasteurised milk, but Huppertz et al. [66] reporting the reverse, which they suggested may be due to increased availability of substrates for bacterial growth due to pressure-induced dissociation of casein micelles.

While a number of authors have thus described the changes in rennet coagulation properties following HP treatment, there have been relatively few studies in which actual cheese is produced from HPtreated milk [110, 123, 136]. Of these, a number also concentrate mainly on cheese composition, yield and textural properties. One of the earliest studies on Cheddar cheese reported that, while HP treatment increased the yield of Cheddar cheese, textural defects resulted from increased incorporation of moisture into cheese [31]. San Martín-González et al. [122] produced Cheddar cheese from milk treated at 483 or $676 \mathrm{MPa}$ at a range of temperatures and found pressure- and temperaturedependent increases in cheese yield and moisture content, and increased cheese hardness.

A number of studies of the biochemical properties of cheese made from raw, pasteurised or HP-treated goats' milk have indicated that the latter had higher levels of incorporated $\beta$-lactoglobulin $(\beta-\lg )$, and altered rates of proteolysis of caseins and profiles of free amino acids during ripening [20, 137] and altered profiles of organic acids [19], while levels of lipolysis in cheese made from HP-treated milk were closer to those in raw milk cheese than in that made from pasteurised milk [17]. The same authors have reported on the textural and microstructural properties of the three types of cheese [21], and have reported that the microbiological quality of cheese made from HP-treated milk was similar to that 
of that made from pasteurised milk [18]. There have also been reports that HP treatment of milk can improve the acceptability of reduced-fat cheese [101].

A recent paper has indicated that treatment of raw milk at $500 \mathrm{MPa}$ for $10 \mathrm{~min}$ reduced an innoculum of Listeria monocytogenes to undetectable levels in both milk and cheese, without significant effects on cheese composition [86]. Another potentially interesting application of HP in cheese involves inactivation of bacteriophage in milk or whey [102].

In terms of potential industrial application, HP treatment involves packaging product into sealed flexible containers (e.g., bags) and immersing them in a pressure-transmitting medium (typically an emulsion or alcohol:oil mixture) in a chamber within which the pressure can be raised to the requisite level and maintained for the desired time, with controlled rates of compression and decompression; the manipulation of pressure is typically attained by use of a piston or high-pressure pumps. This is clearly a batch system and currently available commercial systems treat up to around $300 \mathrm{~kg}$ of product per cycle; the limitations of scale for large cheese factories are thus a possible barrier to implementation. Some semi-continuous plants have been developed where liquids such as milk could be pressure-treated directly by a piston within a chamber called an isolator; connection of several such chambers in sequence but operating out of phase allows semi-continuous operation, but such systems do not seem to have been adopted by the food industry. This, and the very substantial capital investment for HP treatment systems, makes it critical that very attractive advantages for the cheese-maker will need to be proven before commercial adoption is likely (see Patel et al. [114] for a discussion of the hurdles involved in commercialisation of HP in the dairy industry).

\section{HOMOGENIZATION OF CHEESE-MILK}

Since its presentation by Auguste Gaulin at the Paris World Fair in 1899, the homogenizer has become a standard tool in the dairy industry. The primary aim of homogenization of milk is to reduce the size of the fat globules, thereby delaying their creaming rate [69]. In raw milk, fat globule size commonly ranges from $\sim 0.2-15 \mu \mathrm{m}$, and homogenization generally aims to reduce the maximum to $<2 \mu \mathrm{m}$. For this purpose, two-stage valve homogenizers are commonly used, which operate at pressure of $\sim 20 \mathrm{MPa}$. More recently, novel homogenization devices, e.g., high-pressure homogenizers and microfluidisers, which can operate at pressures of several hundred MPa and achieve greater reductions in fat globule size, have been developed [69]. In cheese-making, homogenization of cheese-milk can be of interest for the purpose of preventing creaming of fat globules, reducing fat losses in the whey or controlling development of free fat in the cheese $[71,112,119]$.

Due to the reduction in fat globule size on homogenization, the total surface area of the fat globules increases and the amount of original fat globule membrane material is by far insufficient to fully cover the newly-formed surface [69]. As a result, other surface-active components of milk, primarily caseins and, to a lesser extent, whey proteins, become adsorbed onto the surface of the newly formed globules $[69,146]$. Thus fat globules in homogenized milk almost resemble caseincovered emulsion droplets. The adsorption of caseins onto the fat globules has the following implications for cheese-making characteristics of milk:

(1) casein surface area in milk is increased, but the amount of micellar casein is reduced;

(2) two types of particles with a casein micelle surface layer exist: native casein 
micelles and casein-covered fat globules;

(3) when adsorbed, casein micelles tend to spread over the surface of the fat globule and hence increase in effective surface area but with reduced surfacedensity of $\kappa$-casein.

The rennet coagulation time (RCT) of unhomogenised milk is generally lower than that of homogenized milk [57, 62, $135,149]$. This is probably related to the larger casein surface area in homogenized milk, as well as the lower surface density of $\kappa$-casein. The former increases the probability of interactions between particles, whereas the latter, for a subclass of particles, reduces the amount of $\kappa$-casein that needs to be hydrolyzed before micellar flocculation is induced. Conflicting reports exist on the influence of homogenization on the rate of rennet-induced gel formation; both homogenization-induced increases $[57,62$, 149] and decreases [135] therein have been reported. Zamora et al. [149] reported that, on high-pressure homogenization (100$330 \mathrm{MPa}$ ), the rate of gel formation may be either increased or decreased, with no clear trend as a function of homogenization pressure, but large differences in the $\mathrm{pH}$ of samples hinder a clear and unequivocal interpretation of these data.

Negative aspects of homogenization occur in the subsequent stages of cheesemaking, i.e., the syneresis of the paracasein matrix and the fusion of the paracasein micelles into a strong and cohesive network. Cheese curd from homogenized milk shows poor syneresis $[32,46,62]$ and, as a result, has high moisture content. Furthermore, cheese curd prepared from homogenized milk is also often characterized by a coarse and brittle structure [46, $135,149]$.

The reason for the impaired syneresis of curd prepared from homogenized milk can be traced back to the role of fat globules in the para-casein matrix. In curd from unhomogenised milk, milk fat globules are, on average, of the volume of several thousand para-casein micelles and are distributed throughout the matrix individually or in clusters with areas of up to tens of micrometers [50]. Native fat globules do not interact with the paracasein micelles in the curd matrix and do not participate in syneresis. Hence, they act as plasticizers, with their spatial distribution determining the length scale over which syneresis in the para-casein matrix occurs, and prevent the excessive syneresis of the para-casein matrix that is, for instance, observed in cheese curd made from skim milk [50, 116]. In homogenized milk, the much smaller fat globules are distributed at a considerably smaller length scale, thereby reducing the scale over which syneresis can occur. Furthermore, unlike their unhomogenized counterparts, homogenized milk fat globules do interact with the para-casein matrix, thus reducing the overall effectiveness of the syneresis process because less of the paracasein micelle surface is available for interaction with other micelles $[46,50]$. The already reduced amount of micellar casein present in homogenized (see above) is likely to contribute to this phenomenon.

Cheese made from homogenized milk is generally characterized by an increased moisture content $[47,71,72,84,143]$, which can lead to deviations in ripening profiles. In addition, if cheese from homogenized milk is not heat-treated sufficiently, excessive lipolysis may occur, due to the fact that the membrane of homogenized fat globules is more permeable for lipase than the native milk fat globule membrane [72, 146].

\section{MEMBRANE SEPARATION OF CHEESE-MILK}

Membrane separation processes are commonly applied to separate a liquid under a pressure gradient through a semi-permeable membrane into two liquid 
streams of different composition, the permeate (which flows through the membrane) and the retentate (which concentrates those substances which do not pass through the membrane in a reduced volume of fluid). These processes are applied in dairy processing for an ever-increasing range of applications, e.g., concentration, demineralization, protein separation, or removal of bacteria. Four types of membrane filtration can be distinguished [77, 93, 94]:

(1) ultrafiltration (UF), which selectively separates macromolecules having a molecular mass of 1000 $200000 \mathrm{~g} \cdot \mathrm{mol}^{-1}$;

(2) microfiltration $(M F)$, which selectively separates particles and macromolecules with a molecular mass greater than $200000 \mathrm{~g} \cdot \mathrm{mol}^{-1}$;

(3) nanofiltration $(N F)$, which selectively separates molecules with a molecular weight ranging from 200-1000 g. $\mathrm{mol}^{-1}$;

(4) reverse osmosis ( $R O)$, which separates solutes with a molecular mass smaller than $150 \mathrm{~g} \cdot \mathrm{mol}^{-1}$.

Of these technologies, UF, and, to a lesser extent, MF can be used as a pretreatment for cheese-milk. For an extensive and detailed overview of membrane processing in cheese technology, the reader is referred to the reviews of [96-98].

\subsection{Ultrafiltration}

Essentially, UF enables concentration of casein content and recovery of whey proteins for cheese manufacture [51, 53]. UF of milk at $\mathrm{pH}$ 6.6-6.8 concentrates mineral salts bound to casein micelles in the same proportion as proteins and increases buffering capacity, which affects acidification, $\mathrm{pH}$, rennet coagulation and rheological characteristics of curd [98]. Acidification before or during UF [53] and/or salt addition to retentate leads to solubilisation of colloidal calcium in the permeate.

In cheese-making, three types of UF retentate can be distinguished:

(1) Low-concentration UF retentate: Milk is concentrated a maximum of 2-fold prior to cheese-making, mainly for standardization of protein level. Advantages of this application are increased manufacturing efficiency, reduced rennet requirements and increased cheese yield.

(2) Medium-concentration UF retentate: Milk is concentrated a minimum of 2 -fold and a maximum of 5-fold. This application is presently of little commercial interest.

(3) Liquid pre-cheese: Milk is concentrated to a composition similar to that of the cheese variety to be made, followed by addition of starter culture and subsequent setting with rennet. Processes based on this technology have been developed successfully for the manufacture of some softer cheese varieties, e.g., Camembert, Feta and blue cheese.

During UF, milk runs pressure tangentially across a membrane with a molecular weight cut-off (MWCO) of 1000$200000 \mathrm{~g} \cdot \mathrm{mol}^{-1}$; for cheese-milk, MWCO is generally $<20000 \mathrm{~g} \cdot \mathrm{mol}^{-1}$. Compounds with a molecular mass greater than the MWCO of the membrane, e.g., globular fat, caseins, whey proteins and micellar salts, are selectively concentrated in the UF retentate, whereas those with a molecular smaller than the MWCO, e.g., lactose, serum salts and peptides, are found largely in the UF permeate at their original concentration. This has two major implications for cheese-making properties of milk:

(1) The inter-micellar mean free distance is reduced considerably, from $\sim 200 \mathrm{~nm}$ in unconcentrated skim 
milk [146] to $<10 \mathrm{~nm}$ in skim milk concentrated to a casein content of $\sim 20 \%$ [75]. The reduced inter-micellar mean free distance forces the micelles to interact more frequently with each other as a result of collisions induced by Brownian motion [27, 144].

(2) The buffering capacity of the milk is increased considerably $[96,98]$. This increase in buffering capacity is primarily due to the increased concentrations of proteins and micellar minerals in the UF retentate, both of which are key contributors to the buffering capacity of milk, particularly in the $\mathrm{pH}$ region 5.57.0 [121].

As a result of these changes, the cheesemaking properties of UF retentates differ from those of unconcentrated milk in several aspects. Rennet coagulation time is not affected by concentration if the same amount of rennet is added to unconcentrated or UF concentrate $[42,93,98]$, indicating that the proportion of $\kappa$-casein hydrolyzed at the point of flocculation is lower in UF retentate than in unconcentrated milk, as is indeed observed experimentally [25, 75, 140]. Following 4-fold concentration, hydrolysis of $\sim 50 \%$ of $\kappa$-casein is required to induce gel formation [25] whereas, at $\sim 7$ fold concentration, hydrolysis of only $20 \%$ of $\kappa$-casein is required [75]. The rate of gel firming can also be enhanced by concentration $[97,98]$, although recent studies by Karlsson et al. [75] showed that, following 7-fold concentration (casein content $\sim 20 \%$, w/w), the rate of gel formation of the UF retentate was lower than that of the unconcentrated milk. The reduced coagulation and flocculation rate was related to a high zero-shear viscosity of milk reducing the rate [75].

This emphasises the fact that the rate of gel formation is strongly influenced by both casein concentration and the degree of hydrolysis of the $\kappa$-casein and that optimization is required to maximize the rate of gelation of UF retentates. When cheese-milk was partially supplemented with UF retentate, RCT decreased [113] and increasing protein level resulted in reduced gelation time and increased firming rates [53].

Microstructural analysis by confocal laser scanning microscopy of rennetinduced gels of $\sim 7$-fold concentrated UF retentate revealed that larger rennetinduced casein aggregates are formed in unconcentrated milk than in UF retentate [75]. The degree of macroscopic syneresis, i.e., separation of whey from the gel on a macroscopic level, is considerably less for curd prepared from UF retentate than for curd prepared from unconcentrated milk [75, 117]. Microsyneresis, i.e., re-arrangement of the protein network on a microstructural level, was observed in renneted unconcentrated milk as well as 7-fold concentrated UF retentate, but occurred at a considerably later time-point in the latter [75]. This delay in microsyneresis in a rennet gel from UF retentate is probably due to the fact that micelles therein are still partially covered by $\kappa$-casein at the onset of gelation and thus have a low affinity for binding and subsequent rearrangement and fusion [28, 141]. Further studies on the microstructure of rennet gels prepared from retentate concentrated 2-5 fold by UF are recommended to further our understanding of this area.

Although dependant on concentration factor, adjustment of manufacture protocols, etc., increasing milk protein levels in Cheddar cheese manufacture by use of low-concentration UF results in increased moisture-adjusted yield and actual cheese yield, increased cheese protein, salt-inmoisture, calcium and phosphorous contents and decreased moisture levels [51, 79]. An optimum degree of concentration for making hard cheese varieties of $\sim 1.7: 1$ has been recommended [35, 36, 79].

Cheese made from UF retentate is often characterized by a long time required 
to reach the desired $\mathrm{pH}$ and an acidic taste [96-98] which is related to the higher buffering capacity of a UF retentate. Furthermore, flavour development in hard and semi-hard cheese made from UF retentate is generally slow, which has been related to a reduced rate of proteolysis of caseins during ripening of such cheese $[11,98]$, probably resulting from retention of inhibitors of chymosin and plasmin in the UF retentate [11].

UF of milk to $4-4.5 \%$ protein reduced moisture-in-nonfat-substance (MNFS) levels in cheese made from late-lactation milk to levels similar to those for mid-lactation milk with no significant difference in proteolysis or flavour and with enhanced texture [16]. Increased starter inoculum and reduced cook and Cheddaring temperatures resulted in similar composition and moisture-adjusted yields to control cheeses with improved texture and increased proteolysis in Cheddar cheese manufactured from UF milk [125].

Homogenisation of cream in milks supplemented with UF skim milk to $5.93 \%$ protein resulted in Cheddar cheeses of improved functionality and texture, yields, solids and fat recovery [112]. Protein losses in whey were reported to be similar to those for control cheeses [51] or lower from retentate cheese when expressed as $\mathrm{kg}$ component lost per kilogram cheese obtained [79].

\subsection{Microfiltration}

While applications of MF in cheesemaking are by no means as widely studied as those for UF, there have been some recent developments that are worth noting. First of all, MF may be used for partial microbial decontamination of cheese-milk, as outlined in Figure 1. The "Bactocatch" process $[97,98]$ involves microfiltration of the skim milk using $1.4 \mu \mathrm{m}$ pore size at 37 or $50{ }^{\circ} \mathrm{C}$ to concentrate the mi- crobes in milk in the UF retentate, which, together with the cream, is subjected to a heat treatment, e.g., a UHT treatment at $115-120{ }^{\circ} \mathrm{C}$. The retentate containing bacteria and somatic cells (accounting for $\sim 5 \%$ of the skim milk stream or $\sim 0.5 \%$ if a second MF process is incorporated) may be added to the cream prior to heat treatment; however, thermostable enzymes present may have deleterious effects on subsequent cheese quality [94].

Average decimal reduction of bacteria is $>3.5$ (10 to $50 \mathrm{cfu} \cdot \mathrm{mL}^{-1}$ milk) and is $>4.5$ for sporeforming bacteria, due to binding of bacterial spores to part of the cell wall resulting in larger apparent cell size [94]. Decimal reduction of pathogenic bacteria is $3.5-4.0$ and somatic cells are totally removed [94]. However, milk produced using this process has been described by cheese-makers as 'too clean' and cheese prepared therefrom may lack flavour development as a result. MF results in reduced cheese NSLAB counts, with reduced intensity of cheese flavour and aroma, secondary proteolysis and levels of short-chain volatile acids in Swiss-type cheeses [13] and lower populations of heterofermentative lactobacilli, propionic acid bacteria and enterococci than from raw milk or from pasteurised milk with added MF retentate. However, Roy et al. [120] reported similar counts of Lactobacillus casei and lactococci in both MF and thermised milks but with a lower mesophillic spore count in the latter. Beuvier et al. [13] reported that MF treatment of milk resulted in lower levels of hydrolysis of $\beta$-casein in cheeses than from pasteurised milk; however, Roy et al. [120] proposed that heating of cream or skim milk during MF treatment increased hydrolysis of $\beta$-casein in Cheddar cheese, possibly due to activation of the plasminogen-plasmin activation system. Further optimization is required to achieve desirable ripening characteristics of such cheeses. 


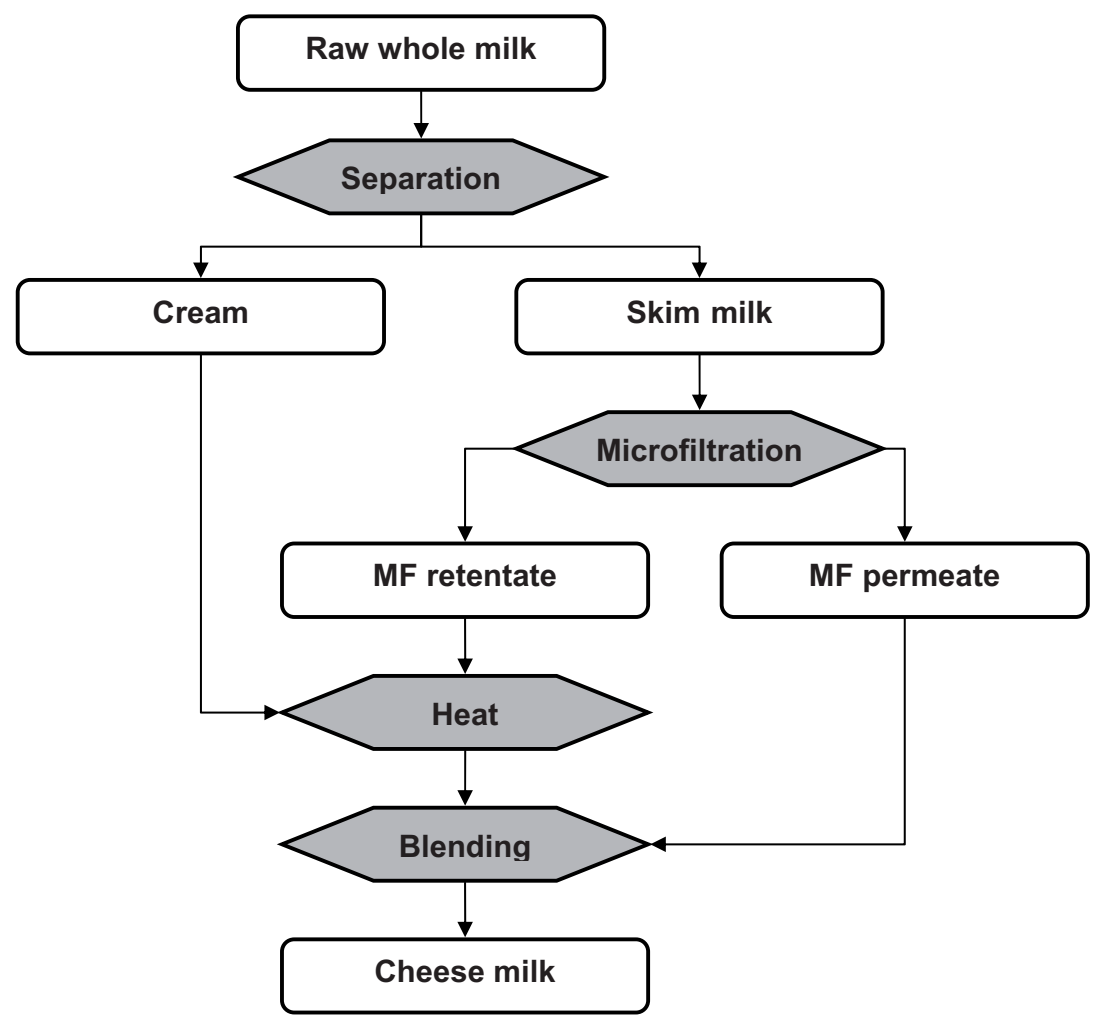

Figure 1. Process for decontamination of milk by microfiltration (adapted from [98]).

A second application of MF in cheesemaking is in standardization of the casein content of milk, rather than the total protein content that is standardized by UF. MF uses larger pore sizes and lower pressures than UF. Whey proteins are smaller molecules ( 3 to $5 \mu \mathrm{m}$ ) compared to casein micelles (15 to $600 \mathrm{~nm}$ ) and can be separated by use of 0.1 to $0.2 \mu \mathrm{m}$ pore size membranes [14]. This separation produces casein enriched retentate and permeates containing significant amounts of native state $\alpha$-lactalbumin and $\beta$-lactoglobulin. MF also concentrates calcium phosphate in the micellar form [105]. Brandsma and Rizvi [14] showed in-process $\mathrm{pH}$ adjustment and microfiltration of acidified skim milk with $0.2 \mu \mathrm{m}$ membrane to produce highly concentrated retentate with reduced
$\mathrm{Ca}$ and whey protein content suitable for use in cheese manufacture.

Casein-enriched milk prepared by MF has been reported to have improved rennet coagulation properties $[95,133]$ and reduced loss of fat and fines in the whey [98]. Increasing MF concentration factor resulted in Mozzarella and Cheddar cheeses with increased moisture, protein and calcium contents, total solids recovery, actual and composition-adjusted cheese yields, proteolysis and flavour and decreased hardness. Increasing chymosin level and adjusting MNFS levels for milk concentrated $1.8 \mathrm{X}$ resulted in Cheddar cheese similar to control cheese $[14,15$, $105,106]$. Furthermore, the MF permeate that is produced is an ideal substrate for production of high quality whey 
protein isolate or further fractionation of individual whey proteins, due to its neutral $\mathrm{pH}$, and lack of residual coagulant or other proteases and lack of caseinomacropeptide [95].

Processes for the extensive concentration of milk by MF, to the point where whey removal subsequent to addition of rennet and starter is minimal or absent, have also been described $[2,15,90]$. The development of proteolytic and functional characteristics of Mozzarella cheese made from MF retentates has been reported to be slower than in control cheeses due to the absence of starter culture, lower levels of rennet used and inhibition of cheese proteolysis due to residual whey proteins in the MF retentates $[2,15]$. This problem may be ameliorated through increased rennet levels, standardisation of curd cook times and addition of starter culture [2, 15, 105].

\section{STANDARDISATION OF CHEESE-MILK BY PROTEIN ADDITION}

Standardisation of milk protein/casein levels, by concentration of milk solids or by producing a protein rich fraction which may be subsequently added to milk prior to cheese manufacture, may be used to reduce some negative defects associated with a seasonal milk supply $[5,52]$, such as variable protein/casein contents which result in poor curd-forming properties and in variations in yield and in composition and consistency of resultant cheeses [3, $83,109]$. Increased yield results from reduced losses of fat and casein particles in whey and better retention of whey proteins in the aqueous phase of cheese. Furthermore, standardisation of milk protein to higher than normal levels enables increased plant throughput without installation of extra cheese vats [52].

Protein standardisation may be achieved by: use of low-concentrated retentate (LCR) produced by UF or RO of cheesemilk; enrichment of casein by MF; or addition of phosphocasein powder (PC) or milk protein concentrate (MPC) [52], typically followed by cheese manufacture using conventional equipment [98]. Addition of denatured microparticulated whey proteins to cheesemilk may also be used to ameliorate defects associated with reduced fat cheese [34, 134].

MPC has the same casein:whey protein ratio as milk [56]. MF of skim milk allows water, lactose, $\alpha$-lactalbumin, $\beta$-lactoglobulin, soluble minerals and NPN to pass through the membrane in the permeate but retains casein in the retentate $[105,106]$. MPC produced by spray drying of retentate from ultrafiltration of skim milk contains $\sim 65 \%$ protein, $3 \%$ fat, $2 \%$ calcium and $20 \%$ lactose [138], while MPC made by ultrafiltration of skim milk and diafiltration contains very little lactose. SMP and skim milk condensed by evaporation contain $\sim 51 \%$ and $14 \%$ lactose respectively [138]. High lactose content in cheese may promote undesirable fermentation, atypical flavour or white crystal defect during cheese ripening [1].

Commercial calcium caseinate produced by acid precipitation is rich in casein but low in minerals. Rennet coagulation time for cheese-milk supplemented with $6 \%$ calcium caseinate powder was significantly higher than for a similar level of supplementation with diafiltered microfiltered DMF or UF retentates [133]. Milk enriched with calcium caseinate before production of low-fat Cheddar produced curd which did not retain fat, possibly due to reduced calcium levels inhibiting coagulation and formation of adequate curd structure, and yields were lower than cheese from DMF powder [133]. PC and MPC have rennet coagulation properties similar to those of milk at similar protein concentration and ionic strength [33, $74,78]$. In a comparative study, increasing milk protein content through standardisation with UFR, MPC or PC resulted 
in enhanced rennet coaguability, reduced gelation time and increased curd firmness but there was no significant effect of protein type [52].

Manufacture of reduced-fat Cheddar cheese from milk standardised with MPC doubled cheese yields per unit weight of milk, significantly increased total solid recoveries, reduced lactose contents and NSLAB counts, but had no significant effect on starter bacteria count, and gave lower levels of FAA and brothy and bitter scores than control cheeses [138]. Decreased levels of primary proteolysis were possibly due to reduced plasmin activity or to addition of chymosin on a volume basis, rather than on a casein basis. Increased moisture-adjusted yield may be due to a high level of whey protein denaturation in the MPC and thus a high level of protein recovery in the MPC-fortified cheese [52]. Standardisation of milk protein content using PC, UFR or MPC resulted in significantly increased fat recovery and yield of cheese per unit weight of milk, normalised to reference levels of casein and fat $[52,56]$. However, as PC is a relatively new ingredient, limited availability could limit its use [52].

Microparticulated whey proteins (produced by microparticulation of whey protein concentrate under conditions of heat and shear) act as a non-interacting filler in the cheese matrix and can mimic the structural properties of fat [91] and may be used in manufacture of low-fat cheese [29]. Lucey and Gorry [89] reported that a commercial microparticulated milk protein had little effect on rennet coagulation; however, Fenelon and Guinee [34] and Guinee et al. [49] reported impaired rennet coagulation properties, with lower curd-firming rates and curd firmness after a fixed renneting time, possibly due to the denatured protein content or dilution of the casein, i.e., the active gel forming component. Addition of microparticulated whey protein resulted in reduced-fat Cheddar with increased moisture and MNFS contents, higher yields, probably due to hydrated whey proteins, lower firmness, but had little effect on or slightly reduced levels of proteolysis and flavour grades [34, 89].

\section{TREATMENT OF CHEESE- MILK WITH EXOGENOUS ENZYMES}

Apart from coagulant, the most common reasons for incorporation of exogenous enzymes in cheese manufacture are: (i) acceleration of ripening, usually by addition of commercial proteinase or lipase preparations; (ii) enhancement of cheese flavour, by addition of peptidases and lipases; (iii) increasing cheese yield, e.g., by addition of transglutaminase or phospholipases. Enzymes (as individual enzymes or as mixtures) may be added to cheesemilk prior to cheese manufacture or during manufacture, alongside the starter or rennet [4]. However, addition of proteinases directly to cheesemilk with rennet or starter culture may prematurely hydrolyse casein, interfere with renneting, and reduce yield [148], and losses of $\sim 90 \%$ of added enzyme at whey drainage are typical [81]. Encapsulation of free enzymes provides an alternative approach to enzyme addition and also enables protection from the outside environment and may allow for controlled release $[44,132]$. One specific approach is the use of liposomes, which are microscopic lipid vesicles comprising an outer shell of phospholipid and an internal aqueous core $[82,118,130,147]$. The potential advantages of liposomes over other methods of enzyme encapsulation for cheese applications are that they are made from materials naturally present in cheese, they protect casein from early hydrolysis during cheesemaking, and they partition well in the curd [148]. 


\subsection{Use of phospholipase}

During cheese manufacture, $85-95 \%$ of milk fat is entrapped in the cheese curd [107] with the remaining fat lost in the whey and, to a lesser extent, in the brine, if used. In manufacture of pasta filata-type cheese, the fat retention rarely exceeds $90 \%$ because of additional losses encountered in the hot stretching step [85]. A new enzymatic method for increasing cheese yield through treating milk with phospholipase prior to cheesemaking has been reported $[60,85,107,108]$. Phospholipase $A_{1}$ (EC 3.1.1.32) hydrolyses the $s n-1$ ester bond of phospholipids, resulting in formation of the less hydrophobic and thus more water-soluble lysophospholipids and fatty acids. It is proposed that lysophospholipids released from the fat globule membranes act as surface-active agents in the cheese curd, which emulsify water and fat during processing and reduces syneresis. Furthermore, $\alpha_{\mathrm{s} 1}$-casein and $\beta$-lactoglobulin interact with lysophopsholipids and also form surface-active lipoprotein complexes [85]. Phospholipases used are specific and have little activity towards di- or tri- glycerides; thus, flavour defects caused by the release of short chain fatty acids are avoided, because phospholipids mainly contain nonvolatile palmitic, oleic and stearic acids.

There have been a small number of studies of the use of phospholipases in cheese applications; no effect of phospholipase treatment of cheese-milk on renneting properties of the cheese-milk has been reported as yet. Hydrolysis of milk phospholipids with a commercial preparation of fungal phospholipase A1 from Fusarium venenatum added to cheese-milk prior to renneting during manufacture of lowmoisture part-skim Mozzarella cheese reduced fat losses in whey and cooking water and increased cheese yield, as a result of improved fat and moisture retention in the cheese curd [60,85]. Despite enzymatic modification of the fat globule mem- brane, the fat globules retained their original size and appearance [85]. Lysophospholipids were retained in the curds in higher amounts compared to native phospholipids, possibly because of interaction with casein and subsequent incorporation into the cheese matrix. It was proposed by Lilbaek et al. [85] that the observed improvement in yield results from improved emulsification and water-holding capacity as a consequence of the presence of lysophospholipids in the curd. No significant differences in cheese microstructure or functionality (melt, stretch, browning) were observed between control cheeses and those treated with phospholipase, and there was no significant effect of phospholipase treatment of cheesemilk on sensory attributes of the cheese or downstream processing of the whey [60].

The potential for further yield improvements by combining use of phospholipase with enrichment of cheesemilk with buttermilk phospholipids to increase the amount of lysophospholipids in the curd was suggested by Lilbaek et al. [85]. Enrichment of cheesemilk with phospholipids from buttermilk or soy milk increased cheese yield and improved the texture of lowfat cheese [30, 45, 97, 99]. Enhanced fat retention has also been reported in fullfat Colby cheese manufactured with added soy lecithin [58].

\subsection{Applications of transglutaminase in cheese-making}

The enzyme transglutaminase (TGase; EC 2.3.2.13) catalyzes the formation of an intermolecular covalent isopeptidebond between protein molecules via an acyl-transfer reaction between the $\varepsilon$-amino group of a lysine residue and the $\gamma$-carboximide groups of a glutamine residue [73]. The caseins are excellent substrates for TGase-induced cross-linking, because of their unfolded native structure. 
For micellar casein, the order of susceptibility to TGase-induced cross-linking is $\kappa-\mathrm{CN}>\beta-\mathrm{CN}>\alpha_{\mathrm{s}}-\mathrm{CN}$, which is predominantly related to the easy of accessibility of the caseins for the enzyme [131]. Lightscattering measurements have shown that, in unconcentrated milk, cross-linking of micellar caseins is exclusively intramicellar and not inter-micellar [64]. This intra-micellar cross-linking stabilizes the micelle against disintegration under unfavourable conditions $[64,131]$ and also has major implications for the hairy brush, consisting predominantly of $\kappa-\mathrm{CN}$, which provides colloidal stability to the micelle [64].

Pre-treatment of milk with transglutaminase increases RCT considerably [63, $88,111]$, and small-deformation oscillatory rheology shows similar trends. When most $\kappa-\mathrm{CN}$ is cross-linked, no rennet-induced flocculation of micelles is observed at all [63]. Cross-linking of caseins in the micellar core is unlikely to be the cause of TGase-induced increases in RCT, since internally cross-linked para-casein micelles, prepared by TGase treatment of casein micelles following cold-renneting, do form a firm coagulum on warming to $30{ }^{\circ} \mathrm{C}$ [111]. Lorenzen [88] and O'Sullivan et al. [111] observed that the amount of CMP released during renneting decreases with increasing degree of cross-linking and concluded therefrom that rennet-induced increases in $\mathrm{RCT}$ are due to a reduction in the rate of enzymatic hydrolysis of $\kappa-\mathrm{CN}$. However, decreases in the rate of release of $\mathrm{CMP}$ do not necessarily indicate that $\mathrm{\kappa}-\mathrm{CN}$ is not hydrolysed, since it can remain attached to the micelles following hydrolysis by chymosin [63]. This point was further highlighted by in-situ diffusing wave spectroscopy measurements during renneting by Huppertz and De Kruif [63] which strongly indicated that the time point at which inter-micellar repulsion is reduced sufficiently to induce micellar flocculation is only increased slightly by TGase- treatment, and that it is the rate of aggregation of these renneted micelles that is reduced.

Studies on the properties of cheese curd or ripening of cheese prepared from milk pre-treated with TGase are, to our knowledge, not available at the moment. However, based on the aforementioned impaired coagulation properties of milk following TGase treatment, it is unlikely that many beneficial effects may be expected in cheese-making.

\section{CONCLUSIONS}

Where centuries ago, cheese was essentially prepared from unprocessed milk, cheese-making nowadays can involve a complex sequence of milk pre-treatments, e.g., membrane filtration, (partial) homogenization and heat treatment. These treatment steps are performed to reach required or desirable characteristics of the milk prior to cheese-making. As outlined in this review, such treatment in general do not only induce the desired change, but are generally accompanied by other changes, which are often less desirable and require adjustment of operations and parameters of the cheese-making process. The recent developments in this area that are described highlight the importance of understanding the manner in which the changes induced by particular pre-treatments of milk will lead to a successful application thereof, and ultimately allow cheese-makers to achieve their goals, e.g., increased yield, consistency, throughput, controlled or accelerated ripening or simply optimal control of food safety.

\section{REFERENCES}

[1] Anderson D.L., Mistry V.V., Brandsma R.L., Baldwin K.A., Reduced-fat Cheddar cheese from condensed milk. 1. Manufacture, composition and yield, J. Dairy Sci. 76 (1993) 2832-2844. 
[2] Ardisson-Korat A.V., Rivzi S.S.H., Vatless manufacture of low-moisture part-skim Mozzarella cheese from highly concentrated skim milk microfiltration retentates, J. Dairy Sci. 87 (2004) 3601-3613.

[3] Auldist M.J., Coats S., Sunderland B.J., Mayes J.J., McDowell G.M., Rogers G.L., Effects of somatic cell count and stage of lactation on raw milk composition and the yield and quality of Cheddar cheese, J. Dairy Res. 63 (1996) 269-280.

[4] Azarnia S., Robert N., Lee B., Biotechnological methods to accelerate Cheddar cheese ripening, Crit. Rev. Biotechnol. 26 (2006) 121-143.

[5] Banks J., The quality of milk in relation to cheese manufacture, J. Soc. Dairy Technol. 43 (1990) 35-39.

[6] Banks J.M., Elimination of the development of bitter flavour in Cheddar cheese made from milk containing heat-denatured whey protein, J. Soc. Dairy Technol. 41 (1988) 37-41.

[7] Banks J.M., Heat treatment of cheese milk, in: Practical guide for control of cheese yield, Special Issue 0001, Int. Dairy Fed., Brussels, Belgium, 2000, pp. 36-39.

[8] Banks J.M., Law A.J.R., Leaver J., Horne D.S., The inclusion of whey protein in cheese - an overview in: Cheese yield and factors affecting its control, Special Issue 9402, Int. Dairy Fed., Brussels, Belgium, 1993, pp. 387-401.

[9] Banks J.M., Law A.J.R., Leaver J., Horne D.S., Maturation profiles of Cheddar-type cheese produced from high heat treatment milk to incorporate whey proteins, in: Malin E.L., Tunick M.H. (Eds.), Chemistry of Structure-Function Relationships in Cheese, Plenum Press, New York, 1995, pp. 221-236.

[10] Banks J.M., Stewart G., Muir D.D., West I.G., Increasing the yield of Cheddar cheese by acidification of milk containing heatdenatured whey protein, Milchwissenschaft 43 (1987) 212-215.

[11] Benfeldt C., Ultrafiltration of cheese milk: effect on plasmin activity and proteolysis during cheese ripening, Int. Dairy J. 16 (2006) 600-608.

[12] Benfeldt C., Sorensen J., Ellegard K.H., Petersen T.E., Heat treatment of cheese milk: Effect on plasmin activity and proteolysis during cheese ripening, Int. Dairy J. 7 (1997) 723-731.
[13] Beuvier E., Berthaud K., Cegarra S., Dasen A., Pochet S., Buchin S., Duboz G., Ripening and quality of Swiss-type cheese made from raw, pasteurized or microfiltered milk, Int. Dairy J. 7 (1997) 311-323.

[14] Brandsma R.L., Rizvi S.S.H., Depletion of whey proteins and calcium by microfiltration of acidified skim milk prior to cheese making, J. Dairy Sci. 82 (1999) 2063-2069.

[15] Brandsma R.L., Rizvi S.S.H., Manufacture of Mozzarella cheese from highly concentrated skim milk microfiltration retentate depleted of whey proteins, Int. J. Food Sci. Technol. 36 (2001) 611-624.

[16] Broome M.C., Tan S.E., Alexander M.A., Manser B., Low-concentration-ratio ultrafiltration for cheddar cheese manufacture. Part 1: Effect on seasonal cheese composition, Aust. J. Dairy Technol. 53 (1998) 510.

[17] Buffa M., Guamis B., Pavia M., Trujillo A.J., Lipolysis in cheese made from raw, pasteurized or high-pressure-treated goats' milk, Int. Dairy J. 11 (2001) 175-179.

[18] Buffa M., Guamis B., Royo C., Trujillo A.J., Microbiological changes throughout ripening of goat cheese made from raw, pasteurized and high-pressure-treated milk, Food Microbiol. 18 (2001) 45-51.

[19] Buffa M., Guamis B., Saldo J., Trujillo A.J., Changes in organic acids during ripening of cheeses made from raw, pasteurized or high-pressure-treated goats' milk, Lebens.Wiss. Technol. 37 (2004) 247-253.

[20] Buffa M., Guamis B., Trujillo A.J., Specific effect of high-pressure treatment of milk on cheese proteolysis, J. Dairy Res. 72 (2005) 385-392.

[21] Buffa M.N., Trujillo A.J., Pavia M., Guamis B., Changes in textural, microstructural, and colour characteristics during ripening of cheeses made from raw, pasteurized or high-pressure-treated goats' milk, Int. Dairy J. 11 (2001) 927-934.

[22] Bulca S., Leder J., Kulozik U., Impact of UHT or heat treatment on the rennet gel formation of skim milk with various whey protein contents, Milchwissenschaft 59 (2004) 590-593.

[23] Calvo M.M., Leaver J., Law A.J.R., Banks J.M., Changes in casein levels during the ripening of Cheddar type cheese made from overheated milk, Milchwissenschaft 47 (1992) 516-518.

[24] Creamer L.K., Matheson A.R., Effect of heat treatment on the proteins of 
pasteurised skim milk, N. Z. J. Dairy Sci. Technol. 15 (1980) 37-49.

[25] Dalgleish D.G., Effect of milk concentration on the rennet coagulation time, J. Dairy Res. 47 (1980) 231-235.

[26] Dalgleish D.G., The enzymatic coagulation of milk, in: Fox P.F. (Ed.), Advanced Dairy Chemistry, Vol. 1, Proteins, Elsevier Science Publications Ltd., London, 1992, pp. 579-620.

[27] De Kruif C.G., Skim milk acidification, J. Coll. Interf. Sci. 185 (1997) 19-25.

[28] Dejmek P., Walstra P., The syneresis of rennet-coagulated curd, in: Fox P.F., McSweeney P.L.H, Cogan T.M., Guinee T.P. (Eds.), Cheese: Chemistry, Physics and Microbiology, Volume 1: General Aspects, 3rd edn., Academic Press, Amsterdam, The Netherlands, 2004, pp. 71-103.

[29] Desai N., Nolting J., Microstructure studies of reduced-fat cheeses containing fat substitute, in: Malin E.L., Tunick M.H. (Eds.), Chemistry of Structure-Function Relationships in Cheese, Plenum Press, New York, 1995, pp. 295-302.

[30] Drake M.A., Chen X.Q., Gerard P.D., Gurkin S.U., Composition and quality attributes of reduced fat cheese as affected by lecithin type, J. Food Sci. 63 (1998) 10181023.

[31] Drake M.A., Harrison S.L., Asplund M., Barbosa-Canovas G., Swanson B.G., High pressure treatment of milk and effects on microbiological and sensory quality of Cheddar cheese, J. Food Sci. 64 (1997) 843-845, 860.

[32] Emmons D.B., Lister E.E., Beckett D.C., Jenkins K.J., Quality of protein in milk replacers for young calves. V. Effect of method of dispersing fat on curd formation and whey syneresis, J. Dairy Sci. 63 (1980) $417-425$.

[33] Famelart M.H., Lepesant F., Gaucheron F., Le Graet Y., Schuck P., pH induced physiochemical modifications of native phosphocaseinate suspensions: Influence of aqueous phase, Lait 76 (1996) 445-460.

[34] Fenelon M.A., Guinee T.P., The compositional, textural, and maturation characteristics of reduced-fat Cheddar made from milk containing Dairy-Lo ${ }^{\mathrm{TM}}$, Milchwissenschaft 52 (1997) 385-389.

[35] Fernandez A., Kosikowski F.V., Low moisture Mozzarella cheese from whole milk retentates of ultrafiltration, J. Dairy Sci. 69 (1986) 2011-2017.
[36] Fernandez A., Kosikowski F.V., Physical properties of direct acidified Mozzarella cheese from ultrafiltered whole milk retentates, J. Dairy Sci. 69 (1986) 643-648.

[37] Fox P.F., Heat induced changes in milk preceding coagulation, J. Dairy Sci. 64 (1981) 2121-2137.

[38] Fox P.F., McSweeney P.L.H., Cheese: an overview, in: Fox P.F., McSweeney P.L.H., Cogan T.M., Guinee T.P. (Eds.), Cheese: Chemistry, Physics and Microbiology, Volume 1, General Aspects, 3rd edition, Elsevier Applied Science, Amsterdam, The Netherlands, 2004, pp. 1-18.

[39] Fox P.F., McSweeney P.L.H., Chemistry and biochemistry of cheese manufacture and ripening, Food Sci. Technol. 20 (2006) 28-32.

[40] Fox P.F., McSweeney P.L.H., Cogan T.M., Guinee T.P. (Eds.), Cheese: Chemistry, Physics and Microbiology, Volume 2, Major Cheese Groups, 3rd edition, Elsevier Applied Science, Amsterdam, The Netherlands, 2004.

[41] Fox P.F., McSweeney P.L.H., Cogan T.M., Guinee T.P. (Eds.), Cheese: Chemistry, Physics and Microbiology, Volume 1, General Aspects, 3rd edition, Elsevier Applied Science, Amsterdam, The Netherlands, 2004.

[42] Garnot P., Influence of milk concentration by UF on enzymatic coagulation, Int. Dairy Fed. Bull. 225 (1988) 11-15.

[43] Ghosh B.C., Steffl A., Hinrichs J., Kessler H.G., Effect of heat treatment and homogenization of milk on camembert-type cheese, Egyptian J. Dairy Sci. 27 (1999) 331-343.

[44] Gibbs B.F., Kermasha S., Alli I., Mulligan C.N., Encapsulation in the food industry: a review, Int. J. Food Sci. Nutr. 50 (1999) 213-224.

[45] Govindasamy-Lucey S., Lin T., Jaeggi J.J., Johnson M.E., Lucey J.A., Influence of condensed sweet cream buttermilk on the manufacture, yield, and functionality of Pizza cheese, J. Dairy Sci. 89 (2006) 454467.

[46] Green M.L., Marshall R.J., Glover F.A., Influence of homogenization of concentrated milks on the structure and properties of rennet curds, J. Dairy Res. 50 (1983) 341-348.

[47] Guinee T.P., Auty M.A.E., Mullins C., Corcoran M.O., Mulholland E.O., Preliminary observations on the effects of fat content and degree of emulsification 
on the structure-functional relationship of Cheddar-type cheese, J. Texture Stud. 31 (2000) 645-663.

[48] Guinee T.P., Fenelon M.A., Mulholland E.O., O'Kennedy B.T., O’Brien N., Reville W.J., The influence of milk pasteurisation temperature and $\mathrm{pH}$ at curd milling on the composition, texture and maturation of reduced fat cheddar cheese, Int. J. Dairy Technol. 51 (1998) 1-10.

[49] Guinee T.P., Gorry C.B., O’Callaghan D.J., O'Kennedy B.T., O'Brien N., Fenelon M.A., The effects of composition and some processing treatments on the rennet coagulation properties of milk, Int. J. Dairy Technol. 50 (1997) 99-106.

[50] Guinee T.P., McSweeney P.L.H., Significance of milk fat in cheese, in: Fox P.F., McSweeney P.L.H. (Eds.), Advanced Dairy Chemistry 2: Lipids, 3rd edn., Springer Verlag, New York, 2006, pp. 377-440.

[51] Guinee T.P., O'Callaghan D.J., Mulholland E.O., Harrington D., Milk protein standardisation by ultrafiltration for cheddar cheese manufacture, J. Dairy Res. 63 (1996) 281293.

[52] Guinee T.P., O’Kennedy B.T., Kelly P.M., Effect of milk protein standardization using different methods on the composition and yields of Cheddar cheese, J. Dairy Sci. 89 (2006) 468-482.

[53] Guinee T.P., Pudja P.D., Mulholland E.O., Effect of milk protein standardisation, by ultrafiltration, on the composition and maturation of cheddar cheese, J. Dairy Res. 61 (1994) 117-131.

[54] Guinee T.P., Pudja P.D., Mulholland E.O., Reville W.J., Ultrafiltration in cheesemaking, in: Cogan T.M. (Ed.), 3rd Cheese symposium, Moorepark, National Dairy Products Research Centre, Moorepark, Fermoy, Co. Cork, Ireland, 1992, pp. 2129.

[55] Guinee T.P., Pudja P.D., Reville W.J., Harrington D., Mulholland E.O., Cotter M., Cogan T.M., Composition, microstructure and maturation of semi-hard cheeses from high protein ultrafiltered milk retentates with different levels of denatured whey protein, Int. Dairy J. 5 (1995) 543-568.

[56] Harvey J., Protein fortification of cheese milk using milk protein concentrate - yield improvement and product quality, Aust. J. Dairy Technol. 61 (2006) 183-185.

[57] Hayes M.G., Kelly A.L., High pressure homogenization of raw whole bovine milk (a) effect on fat globule size and other properties, J. Dairy Res. 70 (2003) 297-305.

[58] Hicks C.L., O’Leary J., Holbrook J., Effect of lecithin on cheese yield, J. Dairy Sci. 68 (1985) 1603-1607.

[59] Hindle E.J., Wheelock J.V., The primary phase of rennet action in heat-sterilized milk, J. Dairy Res. 37 (1970) 389-396.

[60] Høier E., Lilbæk H., Broe M.L., Sørensen N.K., Enhancing cheese yield by phospholipase treatment of cheesemilk, Aust. J. Dairy Technol. 61 (2006) 179-182.

[61] Hotchkiss J.H., Werner B.G., Lee E.Y.C., Addition of carbon dioxide to dairy products to improve quality: a comprehensive review, Comp. Rev. Food Sci. Food Safety 5 (2006) 158-168.

[62] Humbert G., Driou A., Guerin J., Alais C., Effets de l'homogénéisation à haute pression sur les propriétés du lait et son aptitude à la coagulation enzymatique, Lait 60 (1980) 574-594.

[63] Huppertz T., De Kruif C.G., Rennetinduced coagulation of enzymatically cross-linked casein micelles, Int. Dairy J. 17 (2007) 442-447.

[64] Huppertz T., De Kruif C.G., Structure and stability of nanogel particles prepared by cross-linking casein micelles, Int. Dairy J. 18 (2008) 556-565.

[65] Huppertz T., Fox P.F., De Kruif C.G., Kelly A.L., High pressure-induced changes in bovine milk proteins: a review, Biochim Biophys Acta - Prot. Proteomics 1764 (2006) 593-598.

[66] Huppertz T., Fox P.F., Kelly A.L., Influence of high pressure treatment on acidification of bovine milk by lactic acid bacteria, Milchwissenschaft 59 (2004) 246-249.

[67] Huppertz T., Fox P.F., Kelly A.L., Effects of high pressure treatment on the yield of cheese curd from bovine milk, Innov. Food Sci. Emerg. Technol. 5 (2004) 1-8.

[68] Huppertz T., Hinz K., Zobrist M.R., Uniacke T., Kelly A.L., Fox P.F., Effects of high pressure treatment on the rennet coagulation and cheese-making properties of heated milk, Innov. Food Sci. Emerg. Technol. 6 (2005) 279-285.

[69] Huppertz T., Kelly A.L., Physical chemistry of milk fat globules, in: Fox P.F., McSweeney P.L.H. (Eds.), Advanced Dairy Chemistry 2: Lipids, 3rd edn., Springer Verlag, New York, USA, 2006, pp. 173212. 
[70] Imafidon G.L., Farkye N.Y., Composition of cheddar cheese made from high-heat treated milk, in: Cheese Yield and Factors affecting its control, Special Issue 9402, Int. Dairy Fed., Brussels, Belgium, 1993, pp. 433-438.

[71] Jana A.H., Upadhyay K.G., The effect of homogenization conditions on the textural and baking characteristics of buffalo milk Mozzarella cheese, Aust. J. Dairy Technol. 46 (1991) 27-30.

[72] Jana A.H., Upadhyay K.G., Homogenization of milk for cheesemaking - a review, Aust. J. Dairy Technol. 47 (1992) 72-79.

[73] Jaros D., Partschefeld C., Henle T., Rohm H., Transglutaminase in dairy products: chemistry, physics, applications, J. Texture Stud. 37 (2006) 113-155.

[74] Kameswaran S., Smith D.E., Rennet clotting times of skim milk based rennet gels supplemented with an ultrafiltered milk protein concentrate, Milchwissenschaft 54 (1999) 546-550.

[75] Karlsson A.O., Ipsen R., Ardo Y., Rheological properties and microstructure during rennet induced coagulation of UF concentrated milk, Int. Dairy J. 17 (2007) 674-682.

[76] Kelly A.L., O’Donnell H.J., Composition, gel properties and microstructure of Quarg as affected by processing parameters and milk quality, Int. Dairy J. 8 (1998) 295-301.

[77] Kelly P.M., Membrane separation, in: Roginski H., Fuquay J.W., Fox P.F. (Eds.), Encyclopaedia of Dairy Sciences, Academic Press, Amsterdam, The Netherlands, 2003, pp. 1777-1786.

[78] Kelly P.M., Kelly J., Mehra R., Oldfield D.J., Raggett E., O'Kennedy B.T., Implementation of integrated membrane processes for pilot scale development of fractionated milk components, Lait 80 (2000) 139-153.

[79] Kosikowski F.V., Masters A.R., Mistry V.V., Cheddar cheese from retentatesupplemented whole milk, J. Dairy Sci. 68 (1985) 548-554.

[80] Law A.J.R., Banks J.M., Horne D.S., Leaver J., West I.G., Denaturation of the whey proteins in heated milk and their incorporation into Cheddar cheese, Milchwissenschaft 49 (1994) 63-67.

[81] Law B., Kirby C., Microencapsulated enzymes for cheese technology, North Eur. Food Dairy J. 6 (1987) 194-199.
[82] Law B.A., King J.S., Use of liposomes for proteinase addition to Cheddar cheese, J. Dairy Res. 52 (1985) 183-188.

[83] Lawrence R.C., Gilles J., Creamer L.K., Crow V.L., Heap H.A., Honore C.G., Johnston K.A., Samal P.K., Cheddar cheese and related dry-salted cheese varieties, in: Fox P.F., McSweeney P.L.H., Cogan T.M., Guinee T.P. (Eds.), Cheese Chemistry, Physics and Microbiology, Major Cheese Groups, Elsevier Academic Press, Amsterdam, The Netherlands, 3rd edn., Vol. 2, 2004, pp. 71-102.

[84] Lemay A., Paquin P., Lacroix C., Influence of microfluidization on Cheddar cheese composition, quality and yields, in: Cheese yield and Factors Affecting its Control, Special Issue 9402, Int. Dairy Fed., Brussels, Belgium, 1994, pp. 288-292.

[85] Lilbaek H.M., Broe M.L., Hoier E., Fatum T.M., Ipsen R., Sorensen N.K., Improving the yield of Mozzarella cheese by phospholipase treatment of milk, J. Dairy Sci. 89 (2006) 4114-4125.

[86] Linton M., Mackie A.B., Upadhyay V.K., Kelly A.L., Patterson M.F., The fate of Listeria monocytogenes during the manufacture of Camembert-type cheese: a comparison between raw milk and milk treated with high hydrostatic pressure, Innov. Food Sci. Emerg. Technol. 9 (2008) 423-428.

[87] López-Fandiño R., Olano A., Effects of high pressures combined with moderate temperatures on the rennet coagulation properties of milk, Int. Dairy J. 8 (1998) 623-627.

[88] Lorenzen P.C., Renneting properties of transglutaminase-treated milk, Milchwissenschaft 55 (2000) 433-437.

[89] Lucey J.A., Gorry C., Effect of Simplesse 100 on the manufacture of low fat Cheddar cheese, in: Cheese yield and factors affecting its control, Special Issue 9402, Int. Dairy Fed. Brussels, Belgium, 1994, pp. 439-447.

[90] Ma Y., Barbano D.M., Santos M., Effect of $\mathrm{CO}_{2}$ addition to raw milk on proteolysis and lipolysis at $4{ }^{\circ} \mathrm{C}$, J. Dairy Sci. 86 (2003) 1616-1631.

[91] Mackey K.L., Desai N., Rheology of reduced-fat cheese containing a fat substitute, in: Malin E.L., Tunick M.H. (Eds.), Chemistry of Structure-Function Relationships in Cheese, Plenum Press, New York, USA, 1995, pp. 21-26. 
[92] Marshall R.J., Increasing cheese yields by high heat treatment of milk, J. Dairy Res. 53 (1986) 313-322.

[93] Maubois J.-L., Applications of membrane techniques in the dairy industry, Int. Dairy Fed. Bull. 244 (1989) 26-29.

[94] Maubois J.-L., Membrane microfiltration: a tool for a new approach in dairy technology, Aust. J. Dairy Technol. 57 (2002) 92-96.

[95] Maubois J.-L., Fauquant J., Famelart M.H., Caussin F., Milk microfiltrate, a convenient starting material for fractionation of whey proteins and derivatives, in: Proceedings of the 3rd International Whey Conference, Munich, Germany, Sept. 1214: The Importance of Whey and Whey Components in Food and Nutrition, B. Behr's Verlag, Hamburg, Germany, 2001, pp. 57-72.

[96] Mistry V.V., Membrane processing in cheese manufacture, in: Roginski H., Fuquay J.W., Fox P.F. (Eds.), Encyclopedia of Dairy Sciences, Academic Press, Amsterdam, The Netherlands, 2003, pp. 300-306.

[97] Mistry V.V., Maubois J.-L., Application of membrane separation technology in cheese production, in: Fox P.F. (Ed.), Cheese: Chemistry, Physics and Microbiology, Vol. 1., Chapman \& Hall, New York, USA, 1993, pp. 493-522.

[98] Mistry V.V., Maubois J.-L., Application of membrane separation technology in cheese production, in: Fox P.F., McSweeney P.L.H., Cogan T.M., Guinee T.P. (Eds.), Cheese: Chemistry, Physics and Microbiology 1: General Aspects, Academic Press, Amsterdam, The Netherlands, 2004, pp. 261-285

[99] Mistry V.V., Metzger L.E., Maubois J.-L., Use of ultrafiltered sweet buttermilk in the manufacture of reduced fat Cheddar cheese, J. Dairy Sci. 79 (1996) 1137-1145.

[100] Mohammad K.B., Fox P.F., Heat-induced association-dissociation of casein micelles preceeding coagulation, J. Dairy Res. (1987) 377-387.

[101] Molina E., Alvarez M.D., Ramos M., Olano A., López-Fandiño R., Use of highpressure-treated milk for the production of reduced-fat cheese, Int. Dairy J. 10 (2000) 467-475.

[102] Mueller-Merbach M., Rauscher T., Hinrichs J., Inactivation of bacteriophages by thermal and high-pressure treatment, Int. Dairy J. 15 (2005) 777-784.
[103] Nelson B.K., Lynch J.M., Barbano D.M., Impact of milk preacidification with $\mathrm{CO}_{2}$ on Cheddar cheese composition and yield, J. Dairy Sci. 87 (2004) 3581-3589.

[104] Nelson B.K., Lynch J.M., Barbano D.M., Impact of milk preacidification with $\mathrm{CO}_{2}$ on the aging and proteolysis of Cheddar cheese, J. Dairy Sci. 87 (2004) 3590-3600.

[105] Neocleous M., Barbano D.M., Rudan M.A., Impact of low concentration factor microfiltration on the composition and aging of Cheddar cheese, J. Dairy Sci. 85 (2002) 2425-2437.

[106] Neocleous N., Barbano D.M., Rudan M.A., Impact of low concentration factor microfiltration on milk component recovery and cheddar cheese yield, J. Dairy Sci. 85 (2002) 2415-2424.

[107] Nielsen E.W., Principles of cheese production, in: Hui Y.H., Goddik L.M., Hansen A.S., Josephsen J. (Eds.), Handbook of Food and Beverage Fermentation Technology, Marcel Dekker, New York, USA, 2004, pp. 221-239.

[108] Nielsen P.M., Process for producing cheese, U.S. Patent No. 6399121 (2002).

[109] O'Brien B., Mehra R., Connolly J.F., Harrington D., Season variation in the composition of Irish manufacturing and retail milks, 1. Chemical composition and renneting properties, Irish J. Agric. Food Res. 38 (1999) 53-64.

[110] O’Reilly C.E., Kelly A.L., Murphy P.M., Beresford T.P., High pressure treatment: applications to cheese manufacture and ripening, Trends Food Sci. Technol. 12 (2001) 51-59.

[111] O’Sullivan M.M., Kelly A.L., Fox P.F., Influence of transglutaminase treatment on some physico-chemical properties of milk, J. Dairy Res. 69 (2002) 433-442.

[112] Oommen B.S., Mistry V.V., Nair M.G., Effect of homogenization of cream on composition, yield and functionality of Cheddar cheese made from milk supplemented with ultrafiltered milk, Lait 80 (2000) 77-91.

[113] Pandey P.K., Ramaswamy H.S., St-Gelais D., Evaluation of $\mathrm{pH}$ change kinetics during various stages of Cheddar cheesemaking from raw, pasteurized, microfiltered and high-pressure-treated milk, Lebensm.-Wiss. Technol. 36 (2003) 497506.

[114] Patel H., Carroll T., Kelly A.L., New dairy processing technologies, in: Chandan R.C., Kilara A., Shah N.P. (Eds.), Dairy 
Processing Technology and Quality Assurance, Elsevier, London, 465-483.

[115] Pearse M.J., Linklater P.M., Hall R.J., MacKinlay A.G., Effect of heat induced interaction between $\beta$-lactoglobulin and $\kappa$ casein on syneresis, J. Dairy Res. 52 (1985) 159-165.

[116] Pearse M.J., MacKinlay A.G., Biochemical aspects of syneresis: a review, J. Dairy Sci. 72 (1989) 1401-1407.

[117] Peri C., Lucisano M., Donati B., Studies on the coagulation of milk ultrafiltration retentates. 2. Kinetics of whey syneresis, Milchwissenschaft 40 (1985) 650-652.

[118] Reineccius G., Liposomes for controlled release in the food industry, in: Risch S., Reineccius G. (Eds.), Encapsulation and controlled release of food ingredients, American Chemical Society, Washington D.C., 1995, pp. 113-131.

[119] Rowney M.K., Hickey M.W., Roupas P., Everett D.W., The effect of homogenization and milk fat fractions on the functionality of mozzarella cheese, J. Dairy Sci. 86 (2003) 712-718.

[120] Roy D., Pitre M., Blanchette L., Savoie L., Bélanger G., Ward P., Maubois J.-L., Monitoring proteolysis and cheese juice composition during ripening of Cheddar cheese made from microfiltered milk, Lait 77 (1997) 521-541.

[121] Salaun F., Mietton B., Gaucheron F., Buffering capacity of dairy products, Int. Dairy J. 15 (2005) 95-109.

[122] San Martín-González M.F., Rodriguez J.J., Gurram S., Clark S., Swanson B.G., Barbosa-Cánovas G.V., Yield, composition and rheological characteristics of Cheddar cheese made with high pressure processed milk, LWT - Food Sci. Technol. 40 (2007) 697-705.

[123] San Martín-González M.F.J., Welti-Chanes J., Barbosa-Cánovas G.V., Cheese manufacture assisted by high pressure, Food Rev. Int., 22 (2006) 275-289.

[124] Schreiber R., Hinrichs J., Rennet coagulation of heated milk concentrates, Lait 80 (2000) 33-42.

[125] Sharma S.K., Ferrier L.K., Hill A.R., Effect of modified manufacturing parameters on the quality of Cheddar cheese made from ultrafiltered (UF) milk, J. Food Sci. 54 (1989) 573-577.

[126] Singh H., Review: Effects of high temperature on casein micelles, N. Z. J. Dairy Sci. Technol. 23 (1988) 257-273.
[127] Singh H., Creamer L.K., Heat stability of milk, in: Fox P.F. (Ed.), Advanced Dairy Chemistry, Vol. 1, Proteins, Elsevier Science Publications Ltd., London, 1992, pp. 621-656.

[128] Singh H., Fox P.F., Heat stability of milk: $\mathrm{pH}$ dependent dissociation of micellar $\kappa$ casein on heating milk at ultra-high temperatures, J. Dairy Res. 52 (1985) 529-538.

[129] Singh H., Waungana A., Influence of heat treatment of milk on cheese making properties, Int. Dairy J. 11 (2001) 543-551.

[130] Skeie S., Developments in microencapsulation science applicable to cheese research and development. A review, Int. Dairy J. 4 (1994) 573-595.

[131] Smiddy M.A., Martin J.E.G.H., Kelly A.L., De Kruif C.G., Huppertz T., Stability of casein micelles cross-linked by transglutaminase, J. Dairy Sci. 89 (2006) 1906-1914.

[132] Sparkes R.E., Jacobs I.C., Selection of coating and microencapsulation processes, in: Scher H.B. (Ed.), Controlled release delivery systems for pesticides, Marcel Dekker Inc., New York, USA, 1999, pp. 3-28.

[133] St Gelais D., Roy D., Audet P., Manufacture of low fat Cheddar cheese from milk enriched with different protein concentrate powders, Food Res. Int. 31 (1998) 137-145.

[134] Theophilou P., Wilbey A.R., Effects of fat on the properties of halloumi cheese, Int. J. Dairy Technol. 60 (2007) 1-4.

[135] Tosh S.M., Dalgleish D.G., The physical properties and renneting characteristics of the synthetic membrane on the fat globules of microfluidized milk, J. Dairy Sci. 81 (1998) 1840-1847.

[136] Trujillo A.J., Capellas M., Buffa M., Royo C., Gervilla R., Felipe X., Sendra E., Saldo J., Ferragut V., Guamis B., Application of high pressure treatment for cheese production, Food Res. Int. 33 (2000) 311-316.

[137] Trujillo A.J., Royo C., Ferragut V., Guamis B., Ripening profiles of goat cheese produced from milk treated with high pressure, J. Food Sci. 64 (1999) 833-837.

[138] Ur-Rehman S., Farkye N.Y., Considine T., Schaffner A., Drake M.A., Effects of standardization of whole milk with dry milk protein concentrate on the yield and ripening of reduced-fat Cheddar cheese, J. Dairy Sci. 86 (2003) 1608-161.

[139] Van Hooydonk A.C.M., de Koster P.G., Boerrigter I.J., The renneting of heated milk, Neth. Milk Dairy J. 41 (1987) 3-18. 
[140] Van Hooydonk A.C.M., Van de Berg G., Control and determination of the curdsetting during cheesemaking, Int. Dairy Fed. Bull. 255 (1988) pp. 2-10.

[141] Van Vliet T., Van Dijk H.J.M., Zoon P., Walstra P., Relation between syneresis and rheological properties of particle gels, Colloid Polym. Sci. 269 (1991) 620-627.

[142] Vasbinder A.J., Rollema H.S., de Kruif C.G., Impaired rennatability of heated milk: study of enzymatic hydrolysis and gelation kinetics, J. Dairy Sci. 86 (2003) 15481555 .

[143] Versteeg C., Ballintyne P.C., McAuley C.M., Tan S.E., Alexander M., Broome M.C., Control of reduced-fat cheese quality, Aust. J. Dairy Technol. 53 (1998) 106.

[144] Walstra P., Physical Chemistry of Foods, Marcel Dekker Inc., New York, USA, 2003.

[145] Walstra P., van Dijk H.J.M., Geurts T.J., The syneresis of curd. 1. General considerations and literature review, Neth. Milk Dairy J. 39 (1985) 209-246.

[146] Walstra P., Wouters J.T.M., Geurts T.J., Dairy Science and Technology, 2nd edition, CRC Press, Taylor and Francis Group, Boca Raton, USA, 2006.

[147] Weiner N., Phospholipid liposomes: properties and potential use in flavor encapsulation, in: Ho C.T., Tan C.T., Tong C.H. (Eds.), Flavor technology, physical chemistry, modification and process, American Chemical Society Symposium series, Washington, DC, 1995, pp. 210 218.

[148] Wilkinson M.G., Kilcawley K.N., Mechanisms of incorporation and release of enzymes into cheese during ripening, Int. Dairy J. 15 (2005) 817-830.

[149] Zamora A., Ferragut V., Jaramillo P.D., Guamis B., Trujillo A.J., Effects of ultrahigh pressure homogenization on the cheese-making properties of milk, J. Dairy Sci. 90 (2007) 13-23.

[150] Zobrist M.R., Huppertz T., Uniake T., Fox P.F., Kelly A.L., High pressure-induced changes in the rennet coagulation properties of bovine milk, Int. Dairy J. 15 (2005) 655-662. 